\title{
TILLERING DOES NOT INTERFERE ON WHITE OAT GRAIN YIELD RESPONSE TO PLANT DENSITY
}

\author{
Milton Luiz de Almeida ${ }^{1,3 *}$; Luís Sangoi ${ }^{1,3}$; Márcio Ender ${ }^{1}$; Anderson Fernando Wamser ${ }^{2,3}$ \\ ${ }^{1}$ UDESC/CAV - Depto. de Fitotecnia, C.P. 281 - 88520-000 - Lages, SC - Brasil. \\ ${ }_{3}^{2} U F R G S / F A$ - Depto. de Plantas de Lavoura - C.P. 776 - $91501-970$ - Porto Alegre, RS - Brasil. \\ ${ }^{3} \mathrm{CNPq}$ scholar. \\ *Corresponding author <a2mla@cav.udesc.br>
}

\begin{abstract}
Plant density is one of the cropping practices that has the largest impact on individual plant growth. This work was conducted to evaluate the response of white oat (Avena sativa) cultivars with contrasting tillering patterns to variations in plant density. Two field experiments were carried out in Lages, SC, Brazil, during the 1998 and 1999 growing seasons. A split plot experimental design was used. Four oat cultivars were tested in the main plots: UFRGS 14, UFRGS 18, UPF 16 and UPF 17 using five plant densities split plots: 50, 185, 320, 455 and 550 plants $\mathrm{m}^{-2}$. Five plant samples were taken 25, 34, 48, 58 and 70 days after plant emergence to assess the treatment effects on dry matter partition between main stem and tillers. UFRGS 18 promoted dry matter allocation to tillers whereas UPF 17 directed dry mass mostly to the main stem. Differences in dry mass allocation between the main stem and tillers had no impact on grain yield, UPF 16 presenting the highest values for both growing seasons. The lack of interaction between population density and cultivar and the small effect of plant population on grain yield indicates that the oat tillering ability is not fundamental to define its grain yield.
\end{abstract}

Key words: dry mass accumulation, yield components, cultivars

\section{O AFILHAMENTO NÃO INTERFERE NA RESPOSTA DO RENDIMENTO DE GRÃOS DE AVEIA À DENSIDADE DE PLANTAS}

\begin{abstract}
RESUMO: A densidade é uma das práticas de manejo que mais afeta o crescimento individual das plantas. Este trabalho foi conduzido objetivando avaliar a resposta de cultivares de aveia branca (Avena sativa) com diferentes padrões de afilhamento à densidade de plantas. Foram conduzidos dois experimentos em Lages, SC, nos anos de 1998 e 1999. Utilizou-se o delineamento experimental de parcelas subdivididas. Na parcela principal alocou-se quatro cultivares: UFRGS 14, UFRGS 18, UPF 16 e UPF 17. Nas subparcelas testaramse cinco densidades de plantas $\left(50,185,320,455\right.$ e 590 planta $\left.\mathrm{m}^{-2}\right)$. Em 1998 efetuaram-se amostragens de plantas até 70 dias após a emergência para analisar o acúmulo de massa seca no colmo principal (CP) e afilhos. O cultivar UFRGS 18 alocou mais massa seca aos afilhos enquanto que a UPF 17 concentrou mais fitomassa no colmo principal 70 dias após a emergência. As diferenças na partição de assimilados entre CP e afilhos não se manifestaram no rendimento de grãos, sendo o cultivar UPF 16 mais produtivo nos dois anos agrícolas. A ausência de interação entre densidade e cultivares e o pequeno efeito da densidade sobre o rendimento de grãos indicam que o afilhamento não é uma característica fundamental à definição da produtividade da aveia branca.
\end{abstract}

Palavras-chave: acúmulo de massa seca, componentes do rendimento, cultivar

\section{INTRODUCTION}

Plant density is one of the management practices that affects the most individual plant growth and its interactions in the community (Loomis \& Connor, 1992). The ideal number of individuals per unit area must allow maximum yield, without the risk of lack or excess of plants that would hamper grain yield (Mundstock, 1999).

Plant density recommended for oat cropping in the south of Brazil ranges from 200 to 300 viable seeds per square meter (Comissão Brasileira de Pesquisa de Aveia, 2000). This recommendation does not take into account the individual traits of each cultivar, such as plant height, tiller emission and survival, leaf area and cycle length. However, these and other traits interfere with plant density definition, affecting the productive potential of cultivars of different species. In maize, the release of early hybrids, with reduced size and smaller and erect leaves, increased the crop ability to withstand high plant densities (Sangoi, 2001). Density can also affect the growth pattern of the plants. Increasing plant density also increased pod insertion height in the stems of bean plants (Horn et al., 2000), and sped up the sunflower harvesting process (Silva \& Almeida, 1994). 
The influence of density on agronomic characters, associated with the release of cultivars with greater yield potential, reassures the relevance of this subject as a priority research focus. This is particularly important for oat cropping, where breeding programs have put great effort into developing more productive cultivars, capable of better exploiting the available environment (Thomé et al., 2001). This breeding effort may have changed traits such as plant height, dry mass accumulation, leaf area and tillering potential in the new cultivars, possibly interfering with their response to plant density.

The ability to emit fertile tillers is one of the traits that have the greatest impact on the ideal oat plant density. The utilization of high population densities can decrease tillering potential as a result of excessive competition between stalks. On the other hand, the utilization of low densities could be an alternative to explore the tillering ability of the cultivars. In this case, there is a greater possibility that all main stems are productive and, under good environmental conditions, the tillers can also produce panicles. Besides emission, tiller survival is another trait that has been overlooked in determining density in oat cropping. Tillers are only productive when their developmental rate is similar to the main stem development rate (Almeida \& Mundstock, 2001). The increase in competition between plants for environmental factors accelerates the main stem development, in detriment to tillers (Almeida \& Mundstock, 2001).

Another aspect that has not been considered to determinate ideal density of oat plants is dry mass yield in the period that precedes flowering. This yield represents the potential that the community has to invest in grain formation, as long as its harvest index is taken into account. Individuals with greater plant mass can present a large photosynthetic area for carbohydrate production, as well as large panicles, and heavier grains (Boukerrou \& Rasmusson, 1990).

This work was conducted with the objectives of assessing grain yield response to population increase in oat cultivars, identifying the ideal plant density and verifying whether yield response to density is related to dry mass accumulation in stems and tillers in the beginning of the crop cycle.

\section{MATERIAL AND METHODS}

The experiments were carried out during 1998 and 1999, in Lages, SC, Brazil. This city is located in the southern plain of the State of Santa Catarina, $27^{\circ} 52^{\prime} 30^{\prime \prime} \mathrm{S}$ and $50^{\circ} 18^{\prime} 20^{\prime \prime} \mathrm{W}$, at a mean altitude of $930 \mathrm{~m}$, presenting climatic conditions that are favorable for oat growth and development (EPAGRI, 2001). The soil of the experimental area was classified a Dystrupept.
The experimental design was set up as completely randomized blocks arranged in split-plots, with four replicates. Four white oat cultivars (UPF 16, UPF 17, UFRGS 14 and UFRGS 18) were allocated to main plots. Five plant densities $(50,185,320,455$, and 590 plants $\mathrm{m}^{-2}$ ) were tested in the split-plots. In the first year, plants were sampled in five different seasons, which were considered as split-split-plots. Cultivars were chosen based on visual observations of cultivars assessed in the Brazilian Assay of Recommended Oat Cultivars (Ensaio Brasileiro de Cultivares Recomendadas de Aveia), which took place in Lages, in previous years. Cultivars were chosen based on their contrasting tillering ability. Cultivar UFRGS 18 was selected by its great number of tillers, UPF 17 by its low tillering capacity, and cultivars UPF 16 and UPF 14 because of the in intermediate tillering ability.

Soil tillage followed conventional procedures, with one plowing and two harrowings to level the soil. Maintenance fertilization was performed in the sowing furrow, and the fertilizer was incorporated before seed deposition. Fertilization was performed according to soil analysis, following technical recommendations for oat cropping (Comissão Brasileira de Pesquisa de Aveia, 2000).

Sowing was carried out on July 14, 1998 and on July 15, 1999. The amount of seeds was determined according to the desired density for each treatment and results of the germination test previously made for each cultivar. The spacing between rows was $0.20 \mathrm{~m}$ and the sowing depth was $0.05 \mathrm{~m}$. Nitrogen was sidedressed at stage 3.1 in the Haun (1973) scale, at a rate of $30 \mathrm{~kg} \mathrm{ha}^{-1}$. Weeds, diseases and pests were controlled a way to not interfere with crop development. The experiments were conducted under natural precipitation conditions.

During the first year of experiment, each split-plot consisted of 10 rows, five meters in length. In the second year, each split-plot consisted of six rows, five meters in length. The usable area in the split-plots was $3.2 \mathrm{~m}^{2}$, comprising rows number $2,3,4$, and 5 , discarding $0.5 \mathrm{~m}$ at the end of each row. Rows numbered 7, 8, and 9 were utilized to collect plants in 1998. Five samples were taken $25,34,48,58$, and 70 days after emergence of each cultivar, to determine the pattern of accumulation of dry mather (DM) in the main stem (MS) and in the tillers (T). One linear meter was sampled in each collection, leaving $20 \mathrm{~cm}$ as a border crop between adjacent collections taken from the same row. The DM of MS and T were determined for each sampling season.

Plots were harvested at harvest maturation. The following determination were performed: grain yield per hectare at $13 \%$ moisture; yield components, in one linear meter of plants harvested in the usable area number of panicles per plant and per square meter, mass of one thousand grains and number of grains per plant. 
Data were submitted to analysis of variance, and when statistic significance was attained, cultivar means were compared by the Duncan test $(P=0.05)$. A polynomial regression analysis was performed for plant density and DM sampling season, and the equation which best fitted the original data was selected.

\section{RESULTS AND DISCUSSION}

Confirming differences previously observed that motivated the choice of genotypes utilized in this work, the cultivars showed a distinct pattern of DM accumulation in the MS and in T during 1998 (Figures 1 and 2). The increase in DM of MS and T varied in relation to cultivar and density (Figures 1 and 2). Cultivar UFRGS 18 allocated more DM to $\mathrm{T} 70$ days after emergence, at the lowest sowing densities (Figure 2). Cultivar UPF 17 concentrated the allocation of DM to MS in detriment to $\mathrm{T}$ (Figures 1 and 2).

The differences in DM accumulation pattern of MS and T for the different cultivars, as the population increased, did not reflect on grain yield, which was not affected by the interaction between cultivars and densities for the two growing seasons too. In 1998, only a single effect of cultivar was observed, while in 1999 the effects of cultivar and density individually interfered with productivity $(P<0.05)$. Cultivar UPF 16 was the most productive in both cropping seasons, presenting yields higher than $3,000 \mathrm{~kg} \mathrm{ha}^{-1}$ (Table 1). On the other hand, the smallest nominal values of grain yield were recorded for cultivar UFRGS 18, which allocated a smaller amount of DM to the MS and a greater amount to T (Table 1 and Figures 1 and 2).

Plant density quadratically increased cultivar grain yield in 1999 (Figure 3). The optimal density to maximize grain yield was 404 plants $\mathrm{m}^{-2}$. This value is higher than the presently recommended density of 200 to 300 plants $\mathrm{m}^{-2}$ for Brazil (Comissão Brasileira de Pesquisa de Aveia, 2000). However, when the obtained values are analyzed, the productivities recorded for the population range comprised between 185 and 590 plants $\mathrm{m}^{-2}$ were very similar.

Table 1- Grain yield of four white oat cultivars, mean of five plant densities for the 1998 and 1999 cropping seasons.

\begin{tabular}{lcc}
\hline \multirow{2}{*}{ Cultivar } & \multicolumn{2}{c}{ Grain yield } \\
\cline { 2 - 3 } & \multicolumn{1}{c}{1998} & 1999 \\
\hline UPF 16 & $3093 \mathrm{a}$ & $3241 \mathrm{a}$ \\
UFRGS 14 & $3026 \mathrm{ab}$ & $2347 \mathrm{~b}$ \\
UPF 17 & $2523 \mathrm{~b}$ & $2535 \mathrm{~b}$ \\
UFRGS 18 & $2511 \mathrm{~b}$ & $2110 \mathrm{~b}$ \\
\hline MEAN & 2788 & 2559 \\
\hline CV $(\%)$ & 11.4 & 12.9 \\
\hline
\end{tabular}

The absence of significant interaction between density and cultivar, and the moderate effect of density on grain yield in a wide range of plant populations, show that the distinct tillering patterns for cultivars in the beginning of the cycle were not essential to define their final yield. This provides evidence that the evaluated genotypes had adjustment mechanisms for yield components available during the reproductive stage, and that exerted greater influence on grain yield than the differences recorded during initial growth.
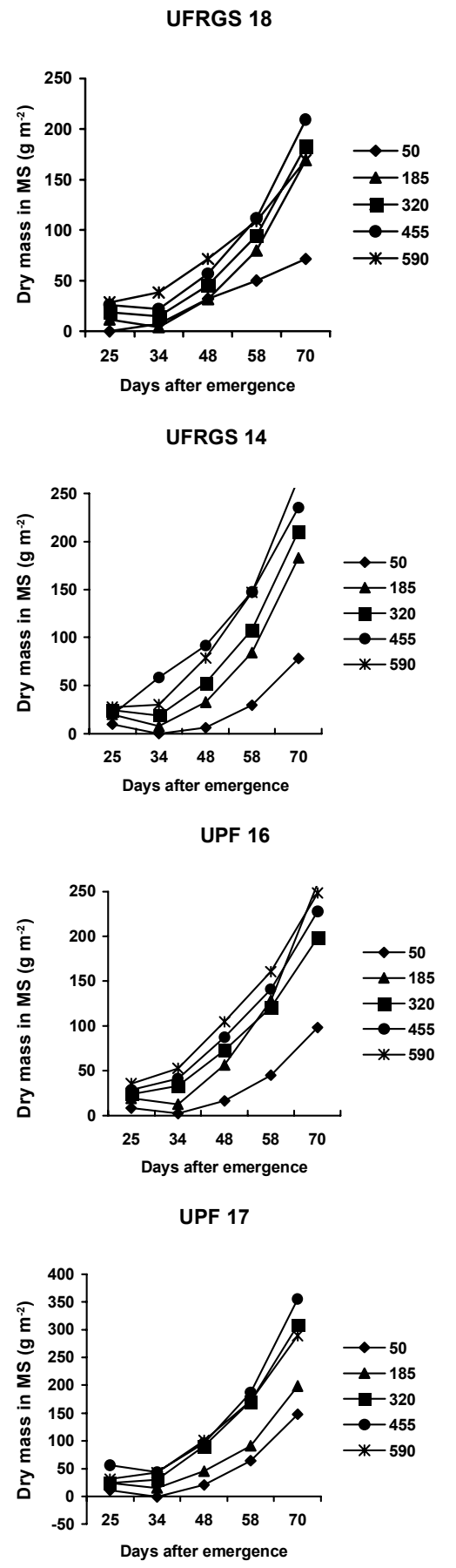

Figure 1- Dry mass of the main stem (MS) of four white oat cultivars at five plant densities as a function of five sampling seasons, 1998. 
The increase in density induced reductions in the number of panicles produced per plant and in the number of grains present in each harvested panicle (Figures 4 and 5). The reduction rates for these yield components varied with cultivar in 1998, while in 1999 there was no interaction between cultivar and density. The opposite behavior was detected for the number of panicles harvested per area, which increased with the increase in density. The increase was quadratic and similar among cultivars in the first cropping season, and linear but differentiated between genotypes in the second season (Figure 6).

UFRGS 18

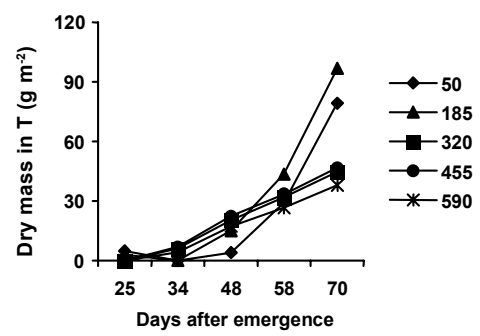

UFRGS 14

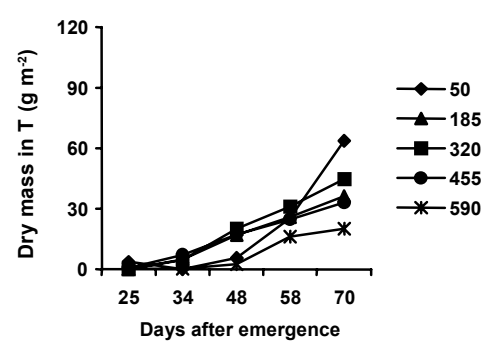

UPF 16

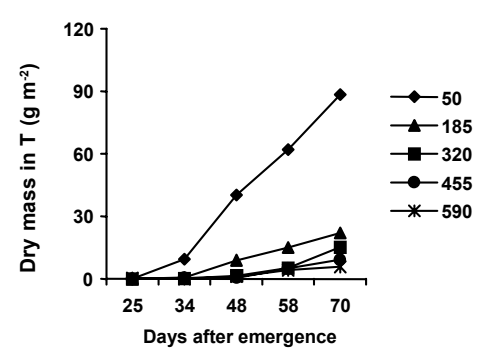

UPF 17

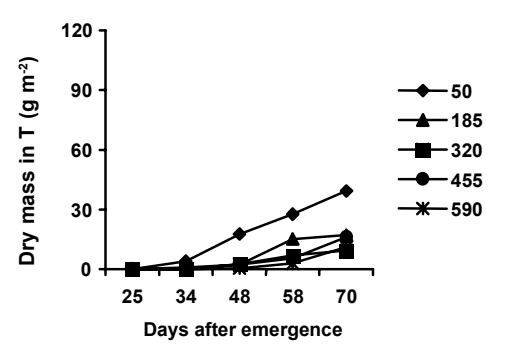

Figure 2 - Dry mass accumulated by tillers (T) of four white oat cultivars at five plant densities as a function of five sampling seasons, 1998.
The mass of 1,000 grains present greater variations; depending rather on cultivar and density than the other yield components. In 1998 the mass of 1,000 grains for cultivar UPF 16 decreased with the increase in density (Figure 7). In 1999, however, there was a reduction in grain mass for cultivar UFRGS 14 and an increase for cultivar UPF 17 with the increase in density. The smallest values for mass of 1,000 grains were recorded for cultivar UFRGS 18, especially in the 1999 cropping season.

The grain yield response to increases in plant density depends on morphological, physiological, and allometric mechanisms of compensation of spaces and on their reflexes over the differentiation and development of reproductive structures in crops (Sangoi, 2001). Species

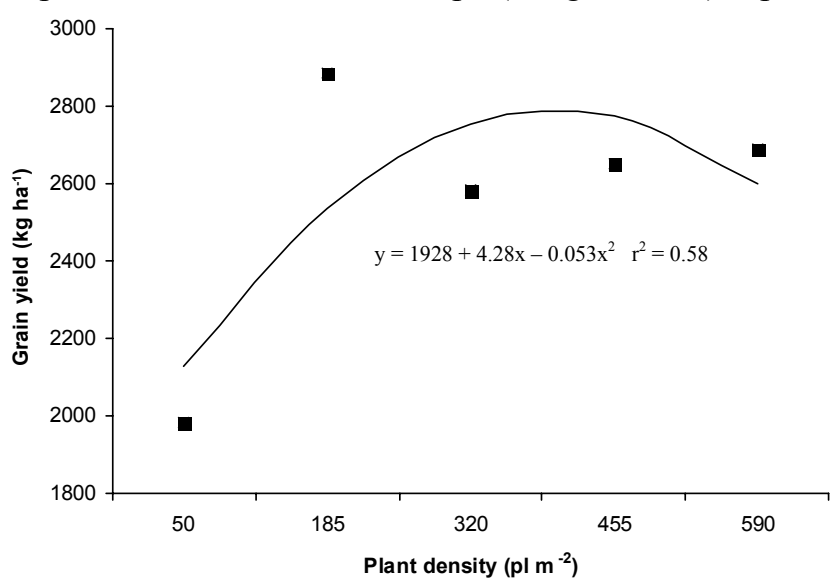

Figure 3 - Grain yield at five plant densities, mean of four white oat cultivars, 1999.
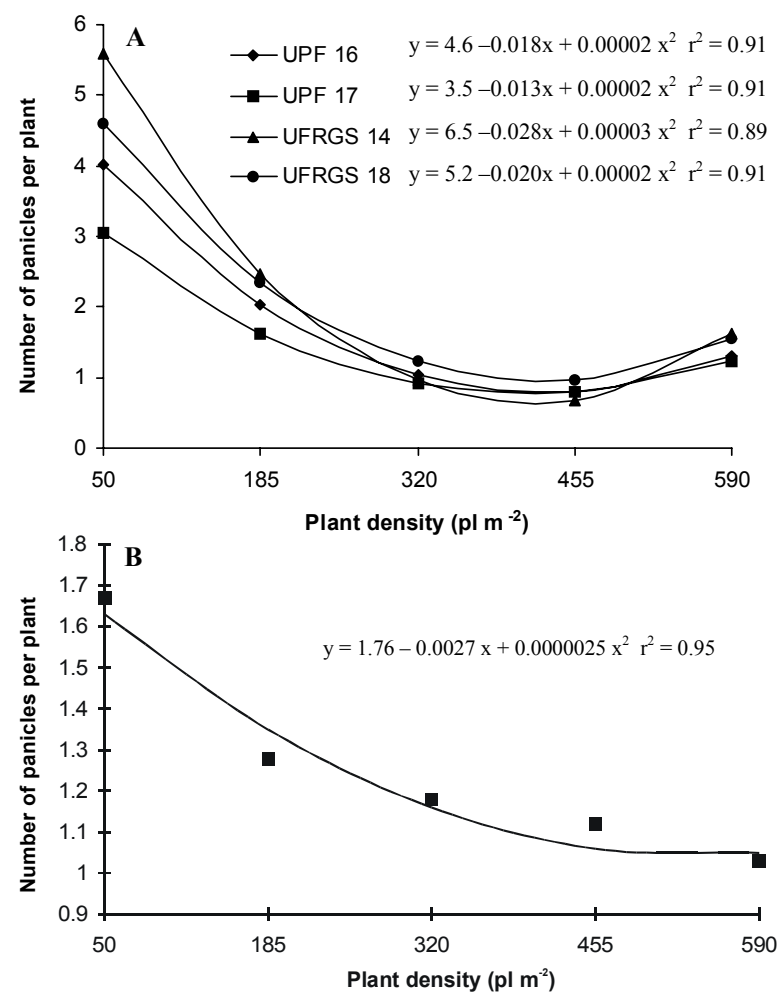

Figure 4 - Number of panicles per plant of white oat cultivars for five plant densities in 1998 (a) and 1999 (b). 

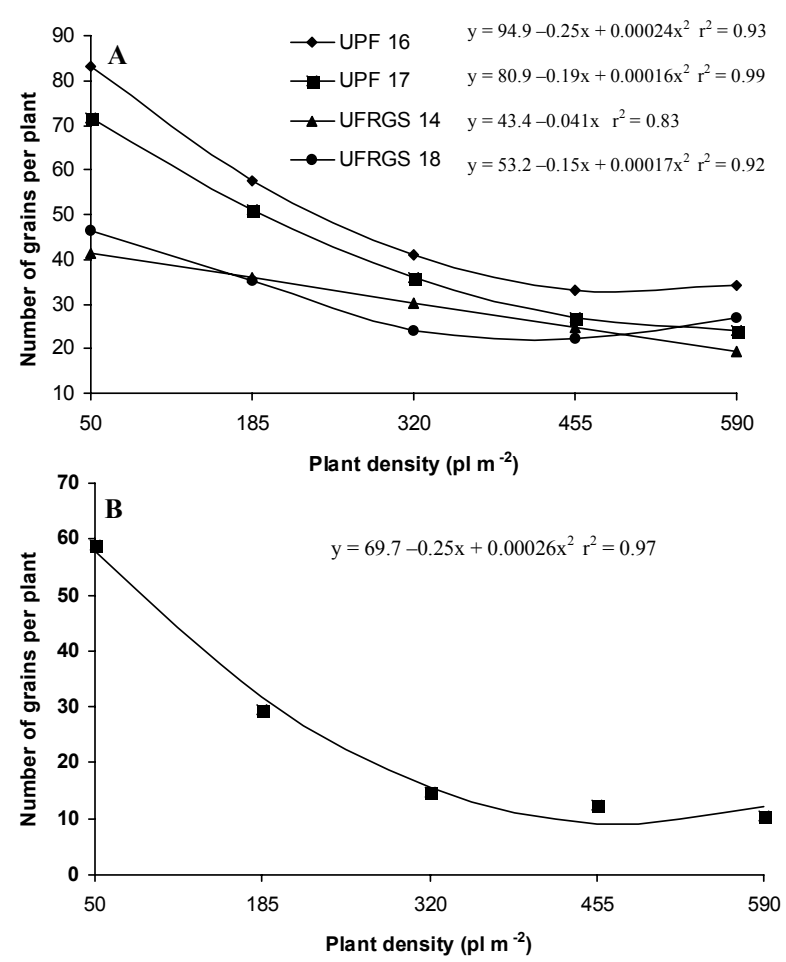

Figure 5 - Number of grains per plant of white oat cultivars for five plant densities in 1998 (a) and 1999 (b).
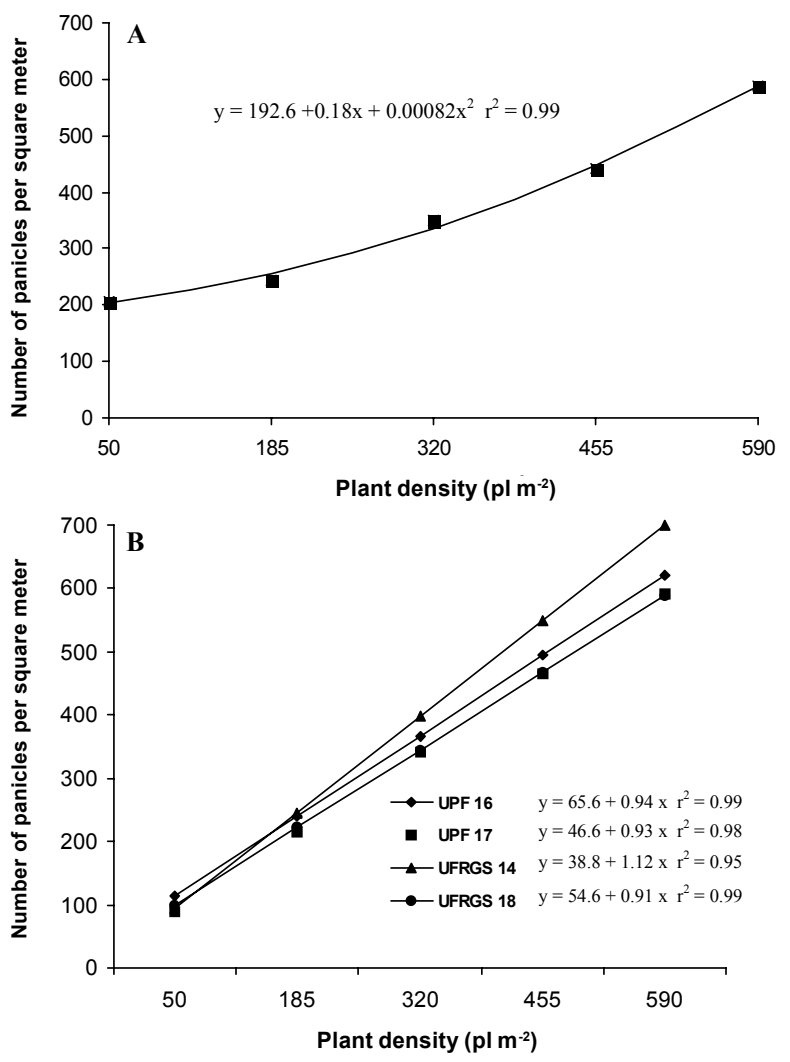

Figure 6 - Number of panicles per square meter of white oat cultivars for five plant densities in 1998 (a) and 1999 (b).

such as oat and soybean show great space compensation capacity when grown at low populations, incresing tiller production and plant ramification, respectively.
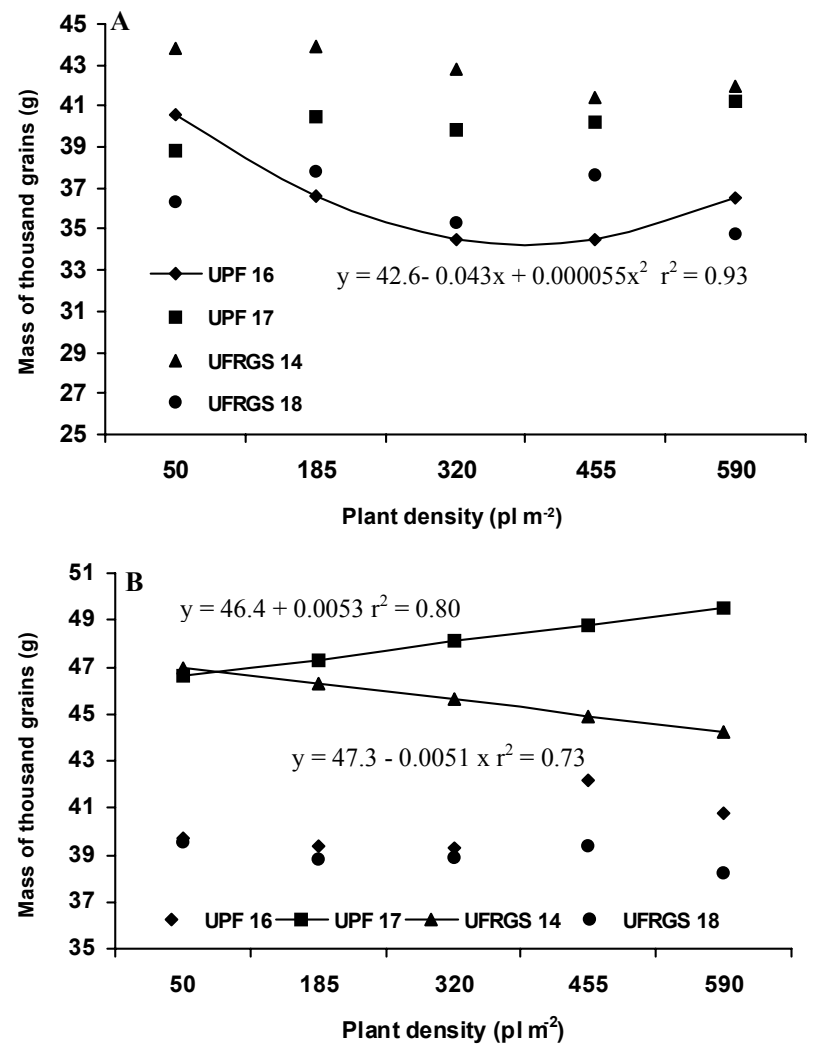

Figure 7 - Mass of one thousand grains of white oat cultivars for five plant densities in 1998 (a) and 1999 (b).

This plasticity is translated into a greater dilution of reproductive meristems, reducing apical dominance and favoring compensation between yield components (Vega et al., 2001).

This type of adjustment did occur in the present work. At a density of 50 plants $\mathrm{m}^{-2}$ the number of panicles produced per plant ranged between 1.5 and 5.0, depending on the cultivar and the cropping season (Figure 4). On the other hand, the utilization of densities higher than 320 plants $\mathrm{m}^{-2}$ limited the production of panicles per plant to 1.0 , regardless of the cultivar's genetic aptitude for tiller emission. The increase in competition for environmental resources in the reproductive stage, as a consequence of greater densities, eliminated any gain that the greater production of tillers in cultivar UFRGS 18 could provide to grain yield, since these tillers were not capable of producing panicles (Figures 2 and 5). The effects of increaseing plant density on grain yield and number of panicles produced per oat plant show that species that belong to the same family could display different responses to variation in intraspecific competition. In maize, Tollenaar et al. (1994) and Sangoi (2001) reported increases in productivity as population density increased, as a result of genotype abilities to adapt to denser stands without drastically reducing the number of ears produced per plant. 
Grain yield in oat is a sequential process where the number of panicles produced per plant is defined firstly, followed by the number of grains fertilized per inflorescence and by the dry mass of grains produced per panicle. When the behavior of yield components shown in Figures 4-7 is analyzed and correlated with yields recorded for the cultivars (Table 1), the most important components that define final yield can be identified. When the most productive cultivar in both cropping seasons (UPF 16) is compared to the cultivar that had the lowest yield (UFRGS 18), the highest productivity values in the first were associated to the greater number of grains produced per plant in 1998 (Figure 5a) and with the greater number of panicles produced per unit area in 1999 (Figure 6b). Therefore, in both years, cultivar UPF 16 yielded greater number of grains per hectare, corroborating ponderations made by Andrade et al. (2000), that this is the yield component that determines the final performance of most crop plants.

Greater tillering capacity is an important trait of compensation of spaces by several grasses under low sowing density, contributing to a better utilization of environmental resources and to increased grain yield (Gardner et al., 1985). The behavior of tiller dry mass, grain yield and components of oat cultivars tested in 1998 show that this compensatory mechanism was not effective in the present work. In general, cultivar UFRGS 18 allocated more dry mass to tillers than cultivar UPF 16 , in the five densities tested (Figure 2). However, this fact did not assure greater productivity, since grain yield for UPF 16 was $23 \%$ higher than for UFRGS 18 in that year. This occurred because the differences in number of panicles produced per plant between the two cultivars were small (Figure 4), showing that the greater concentration of dry mass in tillers did not translate into greater effective tillering. On the other hand, UPF 16 expressed greater grain yield ability per plant, which was decisive for its productive superiority.

The low grain yield response of cultivars to increases in density shows that it is necessary to look for ways of increasing crop tolerance to intraspecific competition at the end of the cycle, when a reduction in yield per plant can be compensated by a greater number of plants present in the area. The genetic differences in tillering ability were not important in defining the productive potential of the tested materials, regardless of the population. The utilization of stands greater than those presently recommended (200 to 300 plants $\mathrm{m}^{-2}$ ) caused all cultivars to yield approximately one panicle per plant. Genetic modifications in tillering ability is probably not the best strategy to obtain greater productivities of this crop.

\section{CONCLUSIONS}

No differential response can be obtained in grain yield of oat cultivars by increasing plant density. Tillering potential is not an essential trait for defining productivity in white oat.

\section{REFERENCES}

ALMEIDA, M.L. de; MUNDSTOCK, C.M. A qualidade de luz afeta o afilhamento em plantas de trigo, quando cultivadas sob competição. Ciência Rural, v.31, p.401-408, 2001.

ANDRADE, F.H.; CIRILO, A.; ECHARTE, L. Factors affecting kernel number in maize. In: OTEGUI, M.; SLAFFER, G.A. (Ed.) Physiological bases for maize improvement. New York: Haworth Press, 2000. cap.5, p.59-71.

BOUKERROU, L.; RASMUSSON, D.C. Breeding for high biomass yield in spring barley. Crop Science, v.30, p.31-35, 1990.

COMISSÃO BRASILEIRA DE PESQUISA DE AVEIA. Recomendações técnicas para a cultura da aveia. Porto Alegre: UFRGS, 2000. 69p.

EMPRESA CATARINENSE DE PEQUISA AGROPECUÁRIA. Avaliação de cultivares para o estado de Santa Catarina 2001/2002. Florianópolis: EPAGRI, 2001. 149p. (Boletim Técnico, 117)

GARDNER, F.P.; PEARCE, R.B.; MITCHELL, R.L. Physiology of crop plants. Ames: Iowa State University, 1985. 327p.

HAUN, J.R. Visual quantification of wheat development. Agronomy Journal, v.65, p.116-119, 1973.

HORN, L.F.; SCHUCH, L.O.B.; SILVEIRA, E.P.; ANTUNES, I.F.; VIEIRA, J.C. MARCHIORO, G.; MEDEIROS, D.F.; SCHWENGBER, J.E. Avaliação de espaçamentos e populações de plantas de feijão visando à colheita mecanizada direta. Pesquisa Agropecuária Brasileira, v.35, p.41-46, 2000.

LOOMIS, R.S.; CONNOR, D.J. Crop Ecology: productivity and management in agricultural systems. New York: Cambridge University Press, 1992. 538 p.

MUNDSTOCK, C.M. Planejamento e manejo integrado da lavoura de trigo. Porto Alegre: UFRGS, 1999. 228p.

SANGOI, L. Understanding plant density effects on maize growth and development: an important issue to maximize grain yield. Ciência Rural, v.31, p.159-168, 2001.

SILVA, P.R.F. da; ALMEIDA, M.L. de. Resposta de girassol à densidade em duas épocas de semeadura e dois níveis de adubação: II Características de planta associadas à colheita. Pesquisa Agropecuária Brasileira, v.29, p.1365-1371, 1994

TOLLENAAR, M.; McCULLOUGH, D.E.; DWYER, L.M.P. Physiological basis of the genetic improvement of corn. In: SLAFER, G.A. Genetic improvement of field crops. New York: Marcel Dekker, 1994. chap.4, p.183-236.

THOMÉ, G.C.H.; MILACH, S.C.K.; FEDERIZZI, L.C. Resistência parcial à ferrugem da folha em genótipos de aveia. Pesquisa Agropecuária Brasileira, v.36, p.393-398, 2001

VEGA, C.R.C.; ANDRADE, F.H.; SADRAS, V.O.; UHART, S.A.; VALENTINUZ, O.R. Seed number as a function of growth. A comparative study in soybean, sunflower and maize. Crop Science, v.41, p.748-754, 2001.

$\overline{\text { Received April 02, }} 2002$ 